\title{
MEDIA CUE CARD UNTUK MENINGKATKAN KETERAMPILAN BERBICARA SISWA SEBAGAI PRAMUWISATA DALAM MENDESKRIPSIKAN TEMPAT WISATA DI KALIMANTAN BARAT UNTUK KELAS X UPW SMK NEGERI 1 PONTIANAK
}

\author{
Lusiana Kristanti \\ SMK Negeri 1 Pontianak, Kalimantan Barat \\ Email: lusianakristanti@gmail.com
}

\begin{abstract}
Abstrak
Cue Card adalah sebuah media dari kertas berbentuk kartu yang berisi kata-kata kunci yang penting sesuai dengan topik yang sedang dibahas. Dalam proses pembelajaran, siswa dibimbing untuk membuat Cue Card mereka sendiri yang berisi tentang topik-topik utama yang mendeskripsikan tentang sebuah tempat wisata. Siswa berhasil meningkatkan kemampuannya dalam melakukan pemanduan dengan menggunakan Bahasa Inggris, yang dapat terlihat dari video presentasi dan peningkatan nilai siswa dalam melakukan pemanduan dengan menggunakan Bahasa Inggris. Sebagai kesimpulan penggunaan media Cue Card efektif dalam meningkatkan keterampilan siswa berbicara sebagai pramuwisata dalam Bahasa Inggris.
\end{abstract}

Kata Kunci : Cue Card, Ketrampilan Berbicara, Pemanduan Wisata, Deskripsi tempat wisata

\begin{abstract}
Cue Card is a paper-based media containing key words that are important in accordance with the topic being discussed. In the learning process, students are guided to make their own Cue Cards which contain the main topics that describe a tourist attraction. Students succeeded in improving their ability to guide using English, which can be seen from video presentations and increasing the value of students in conducting guides using English. In conclusion, the use of Cue Card media is effective in improving students' speaking skills as guides in English.
\end{abstract}

Keywords: Cue Card, Speaking Skills, Tourist Guides, Description of tourist attractions

\section{PENDAHULUAN}

Pendidikan adalah hal yang sangat penting dalam proses kehidupan seseorang. Bertumbuh kembangnya seseorang melalui proses kehidupan yang panjang, dan salah satu faktor pendukung adalah pendidikan. Tanpa pendidikan yang baik maka tumbuh kembang seseorang akan menjadi pincang. Oleh karena itu pendidikan bukan hanya menjadi tanggung jawab pihak orang tua dan keluarga, tetapi juga menjadi tanggung jawab pihak pemerintah. Maka dikembangkanlah sistem pendidikan di sebuah negara sebagai sebuah panduan bagaimana pendidikan tersebut dikembangkan di negara tersebut.

Pendidikan menengah kejuruan dikelompokkan dalam bidang kejuruan didasarkan pada perkembangan ilmu pengetahuan, teknologi, dan/atau seni, dunia industri/dunia usaha, 
ketenagakerjaan baik secara nasional, regional maupun global, kecuali untuk program kejuruan yang terkait dengan upaya-upaya pelestarian warisan budaya. Dalam tulisan ini penulis melakukan inovasi pembelajaran di SMK Negeri 1 Pontianak karena penulis adalah guru Bahasa Inggris di sekolah tersebut. Inovasi yang dilakukan oleh peneliti dilakukan pada siswa kelas X jurusan Usaha Perjalanan Wisata.

Salah satu kompetensi yang harus dikuasai siswa dan diujikan dalam praktik Uji Kompetensi Keahlian (UKK) dengan menggunakan Bahasa Inggris adalah Bekerja sebagai Pramuwisata (Tour Conducting) dengan kode PARUJPFTG01C dan kompetensi ini sesuai dengan KD 4.4 yaitu menyusun teks deskriptif lisan dan tulis, pendek dan sederhana, terkait orang, benda dan tempat, dengan memperhatikan fungsi sosial, struktur teks, dan unsur kebahasaan, secara benar dan sesuai konteks, sehingga pada pelajaran Bahasa Inggris siswa dapat melatih keterampilan berbicara mereka sebagai pramuwisata. Sesuai dengan tuntutan kompetensi yang diminta bagi siswa lulusan UPW SMK maka dalam UKK siswa diwajibkan untuk melakukan praktik pemanduan wisata dengan menggunakan Bahasa Inggris. Dalam praktiknya pada saat siswa melakukan praktik pemanduan wisata dengan menggunakan Bahasa Inggris sebagian besar siswa mengalami kesulitan.

Salah satu masalah yang dialami siswa adalah kesulitan untuk menghafal materi pemanduan yang harus mereka lakukan dengan menggunakan Bahasa Inggris. Para siswa terbiasa melakukan praktik pemanduan berdasarkan teks yang telah mereka buat dan kemudian mereka hafalkan. Hal ini dilakukan berdasarkan proses pembelajaran yang dilakukan guru dengan cara meminta siswa untuk membuat sebuah teks pemanduan wisata untuk tempat wisata yang mereka ingin pandu dan kemudian dihafalkan di depan kelas secara individual. Proses menghafal tersebut adalah sebuah proses yang tidak mudah dilakukan, terutama siswa menghafalnya dalam Bahasa Inggris. Proses untuk presentasi melakukan pemanduan ke depan kelas juga merupakan sebuah tantangan bagi siswa, sehingga siswa menghadapi dua kesulitan sekaligus dalam penguasaan kompetensi Pemanduan Wisata (Tour Conducting). Oleh karena itu siswa memerlukan sebuah cara yang efektif dalam membantu mereka untuk mempermudah praktik pemanduan wisata dengan menggunakan Bahasa Inggris.

Penulis selaku guru Bahasa Inggris mencoba untuk menerapkan beberapa metode pembelajaran untuk membantu siswa menghadapi masalah mereka dalam praktik pemanduan tersebut. Tetapi metode tersebut masih belum dapat membantu siswa secara maksimal. Berkaitan dengan permasalahan tersebut, maka peneliti selaku guru Bahasa Inggris di SMK Negeri 1 Pontianak berkolaborasi dengan guru produktif yang mengampu kompetensi pemanduan wisata akan melakukan penelitian dengan menggunakan Cue Card untuk meningkatkan kemampuan siswa pada kompetensi Pemanduan Wisata (Tour Conducting). Cue Card adalah sebuah media dari kertas dibuat dalam bentuk kartu yang berisi kata-kata kunci yang penting sesuai dengan topik yang sedang dibahas. Berdasarkan pendapat Nunan dalam Cue Card ide - ide pokok yang akan digunakan untuk menjelaskan topik yang dibahas dituliskan dalam sebuah kartu. Hal ini akan membantu seseorang yang akan melakukan presentasi mengingat materi yang harus mereka tampilkan. Cue Card dapat digunakan untuk membantu siswa jurusan UPW dalam melakukan praktik pemanduan dengan Bahasa Inggris. Sehingga permasalahan siswa dalam menghafal dapat diperkecil karena mereka memiliki alat bantu dalam bentuk media Cue Card untuk mengingat hal-hal apa saja yang mereka akan praktikkan dalam proses pemanduan dengan menggunakan Bahasa Inggris. 
Dalam proses pembelajaran siswa dibimbing untuk membuat Cue Card mereka sendiri yang berisi tentang topik-topik utama yang akan mereka deskripsikan tentang sebuah tempat wisata. Harapannya adalah dengan menggunakan Cue Card itu siswa dapat terbantu dalam melakukan pemanduan sebuah tempat wisata karena mereka tidak perlu menghafal secara keseluruhan, tetapi mereka hanya menggunakan topik-topik yang mereka tulis dalam Cue Card. Sehingga siswa akan mendapatkan pengalaman belajar yang menyenangkan untuk materi pemanduan dalam Bahasa Inggris karena masalah mereka dalam menghafal materi pemanduan mereka dapat dipecahkan.

Permasalahan dalam artikel ini dirumuskan sebagai berikut: (1) Bagaimanakah proses pembelajaran dalam meningkatkan keterampilan siswa berbicara dengan menggunakan Bahasa Inggris sebagai pramuwisata untuk siswa Kelas X Jurusan Usaha Perjalanan Wisata SMK Negeri 1 Pontianak? (2) Bagaimanakah hasil peningkatan keterampilan berbicara dengan menggunakan Bahasa Inggris sebagai pramuwisata untuk siswa Kelas X Jurusan Usaha Perjalanan Wisata SMK Negeri 1 Pontianak?

Tujuan penelitian ini untuk mendeskripsikan Strategi Pemecahan Masalah yang dipilih. Strategi pemecahan masalah siswa kesulitan untuk menghafal materi pemanduan yang harus mereka lakukan dengan menggunakan Bahasa Inggris adalah dengan menggunakan media Cue Card saat mereka melakukan praktik sebagai pramuwisata untuk mendeskripsikan sebuah tempat wisata di Kalimantan Barat dengan menggunakan Bahasa Inggris. Dalam penjelasan tahapan operasional pelaksanaannya, siswa mendapat tugas untuk membuat Cue Card tentang topik-topik yang akan mereka sampaikan sebagai pramuwisata dalam mendeskripsikan sebuah tempat wisata di Kalimantan Barat.

Penelitian ini diharapkan dapat bermanfaat untuk memperkaya khazanah ilmu pengetahuan kebahasaan dan pembelajarannya, terutama dalam kegiatan berbicara dalam Bahasa Inggris. Bagi guru, penelitian ini juga menawarkan inovasi dalam pembelajaran berbicara, memberi solusi atas kesulitan pelaksanaan pembelajaran berbicara, dan meningkatkan kemampuan guru dalam merencanakan serta menerapkan media pembelajaran dengan menggunakan cue card. Bagi siswa, penelitian ini membantu mengatasi kesulitan pembelajaran berbicara dalam Bahasa Inggris. Bagi sekolah, penelitian ini menumbuhkan suasana belajar yang menyenangkan dalam proses pembelajaran sehingga dapat meningkatkan mutu pendidikan di SMK Negeri 1 Pontianak.

Dalam penelitian ini penulis menggunakan media Cue Card untuk meningkatkan keterampilan berbicara siswa sebagai pramuwisata dalam mendeskripsikan tempat wisata di Kelas X UPW SMK Negeri 1 Pontianak semester genap tahun pelajaran 2018/2019. Peneliti menggunakan kertas buffalo yang kemudian digunting oleh siswa menjadi bentuk Cue Card. Dalam Cue Card tersebut siswa menuliskan topik-topik apa saja yang akan mereka gunakan untuk mendeskripsikan sebuah tempat wisata di Kalimantan Barat. Pada saat membuat Cue Card siswa akan bekerja secara berkelompok meskipun masing-masing siswa membuat Cue Card nya secara individual. Adapun tujuan siswa bekerja secara berkelompok agar mereka dapat saling membantu pada proses pembuatan Cue Card tersebut. Kemudian setelah siswa selesai membuat Cue Card, mereka akan melakukan presentasi lisan dan berperan sebagai seorang pramuwisata dan mendeskripsikan tempat wisata sesuai dengan Cue Card yang telah mereka buat. 


\section{LANDASAN TEORI}

\section{Keterampilan Berbicara}

Salah satu keterampilan dalam Bahasa Inggris adalah keterampilan berbicara. Proses berbicara adalah proses mengucapkan kata dan kalimat yang memiliki makna secara lisan. Brown (2001:251) menyatakan bahasa lisan meliputi: (1) Monolog baik yang terencana yaitu seseorang menyampaikan sesuatu secara lisan dengan konsep dan persiapan maupun tanpa rencana yaitu menyampaikan sesuatu secara lisan tanpa konsep dan persiapan. (2) Dialog yang dapat berupa dialog interpersonal yang melibatkan dua atau lebih pembicara dan para pembicara saling berkomunikasi dan memiliki perannya masing-masing, ataupun dialog transaksional yang bertujuan untuk menyampaikan sesuatu hal atau informasi yang faktual.

Sedangkan menurut Brown and Yule dalam Richard keterampilan berbicara dibagi menjadi tiga: (1) Keterampilan berbicara untuk berinteraksi yaitu keterampilan berbicara berkaitan dengan kemampuan berinteraksi secara sosial. Sebagai contoh keterampilan berinteraksi pada saat bertemu, kita akan saling mengucapkan salam, berbicara hal yang sifatnya ringan atau saling berbagi pengalaman. Hal ini dilakukan agar kita dapat saling berinteraksi secara nyaman satu dengan lainnya. Aspek - aspek keterampilan berbicara untuk berinteraksi adalah sebagai berikut: membuka dan menutup percakapan, memilih topik, melakukan percakapan yang sifatnya ringan, bergurau, interaksi antar pembicara, menginterupsi, menggunakan gaya berbicara yang sesuai. (2) Keterampilan berbicara untuk bertransaksi yaitu keterampilan berbicara untuk bertransaksi fokus pada apa yang diucapkan atau apa yang dilakukan. Berarti hal yang ditekankan adalah bagaimana hal yang diucapkan dapat diterima oleh pihak yang diajak berinteraksi dengan baik dan benar. Sebagai contoh pada saat guru menjelaskan materi pembelajaran di kelas, isi penjelasan lisan oleh guru harus dapat dipahami oleh siswa sebagai partner guru dalam berinteraksi di dalam kelas. (3) Keterampilan berbicara di depan umum yaitu keterampilan ini berkaitan dengan kemampuan secara monolog untuk tampil berbicara menyampaikan informasi di hadapan penonton atau peserta, seperti menampilkan presentasi di depan kelas, menyampaikan pengumuman atau pidato di depan umum.

Penelitian ini menggunakan aspek keterampilan berbicara di depan umum karena siswa akan menyampaikan monolog pemanduan wisata deskripsi tentang tempat wisata di Kalimantan Barat dalam Bahasa Inggris dengan menggunakan media Cue Card.

\section{Teks Deskriptif}

Deskripsi berasal dari kata dalam Bahasa Inggris describe yang artinya adalah menggambarkan. Berdasarkan Kane (1988:7) deskripsi berhubungan dengan persepsi-persepsi visual umum. Artinya dalam mendeskripsikan sesuatu atau tempat kita menuliskan atau menuturkan sesuatu yang konkret seperti warna, ukuran, bentuk, atau bahan objek yang sedang dijelaskan.

Provost (2009:1) dalam sebuah artikel How to Write a Descriptive Paragraph atau Bagaimana Cara Menulis Paragraf Deskriptif mengatakan bahwa paragraf deskriptif mencakup hal-hal yang berkaitan dengan panca indra penglihatan, rasa, sentuhan, penciuman dan pendengaran. Hal ini berarti pada sebuah teks deskriptif terdapat informasi yang berkaitan dengan panca indra untuk memberikan deskripsi terbaik bagi pembaca atau pendengar. Hal ini juga dikatakan oleh Zemach dan Islam (2005:21) bahwa ketika seseorang mencoba untuk menggambarkan sesuatu atau tempat maka penulis 
atau penutur harus menambahkan rincian deskriptif yang berkaitan dengan informasi yang menceritakan bagaimana sesuatu atau tempat terlihat, terdengar, tercium dan dirasakan. Hal ini berati dalam membuat sebuah teks deskriptif, kita harus merinci objek yang kita jelaskan sesuai dengan panca indra pendengaran, penglihatan, perasa dan penciuman sehingga pembaca atau pendengar dapat mendapatkan informasi secara detail tentang gambaran objek yang diceritakan.

\section{Cue Card}

Media memegang peranan penting dalam proses pembelajaran Bahasa Inggris. Karena penggunaan media dapat mempermudah siswa melakukan aktivitas pembelajaran. Media pendidikan adalah instrumen, ide, alat atau orang yang memanipulasi metode dan teknik untuk menyampaikan informasi untuk berkomunikasi dan berinteraksi lebih efektif di antara guru dan siswa dalam proses belajar mengajar. Media tidak hanya berfungsi sebagai alat untuk membantu guru tetapi juga meningkatkan efektivitas kegiatan belajar mengajar. Ini berarti media dapat membantu siswa mengarahkan tujuan pembelajaran. Hal ini sejalan dengan teori yang diungkapkan oleh Reiser dan Dick (1996: 70) yang menyatakan bahwa media sering digunakan untuk membantu menyajikan kegiatan pembelajaran. Dengan kata lain, penggunaan berbagai media dapat mengurangi kebosanan di kelas, dan itu juga menarik bagi gaya belajar siswa yang berbeda. Menurut Harmer (2007:134) salah satu bentuk media adalah gambar. Gambar yang dapat digunakan dalam bentuk flashcard, wall pictures, cue card, foto, dan ilustrasi.

Oleh karena itu berdasarkan teori Harmer di atas, maka salah satu media pembelajaran yang dapat digunakan untuk meningkatkan keterampilan berbicara dalam Bahasa Inggris adalah Cue Card. Media Cue Card ini dibuat dari kertas berbentuk kartu yang berisi ide-ide yang dikembangkan berdasarkan topik.

Menurut Nunan (2003) Cue Card dapat digunakan dalam penyajian presentasi atau monolog. Dalam Cue Card dapat ditulis ide secara terstruktur untuk presentasi. Dengan menggunakan Cue Card masalah siswa dalam berbicara dapat dikurangi karena tidak semua siswa memiliki kemampuan untuk menghafal presentasi yang mereka harus tampilkan di depan kelas. Cue Card dapat membantu siswa karena di dalamnya siswa dapat menuliskan ide-ide pokok materi pemanduan wisata yang harus mereka tampilkan dengan menggunakan Bahasa Inggris.

\section{Implementasi}

Dalam pelaksanaannya digunakan 3 x 2 jam pembelajaran untuk pelaksanaan kegiatan ini. Pada awal kegiatan siswa akan mendapat penjelasan dari guru tentang kegiatan mereka yang dimulai dari penjelasan tentang apa itu teks deskripsi, pembuatan Cue Card yang isinya topik-topik yang akan mereka sampaikan pada saat praktik menjadi seorang pramuwisata dan praktik sebagai seorang pramuwisata untuk mendeskripsikan sebuah tempat wisata di Kalimantan Barat.

Disesuaikan dengan Kurikulum 2013 maka materi teks deskriptif diberikan pada siswa jenjang kelas $\mathrm{X}$. Maka rencana yang disusun oleh penulis adalah sebagai berikut: 
Tabel 2.1 Kompetensi Dasar (KD) dan Indikator Pencapaian Kompetensi (IPK)

\begin{tabular}{ll}
\hline \multicolumn{1}{c}{ Kompetensi Dasar } & \multicolumn{1}{c}{ Indikator Pencapaian Kompetensi } \\
\hline $\begin{array}{l}\text { 3.4 Menganalisis fungsi sosial, struktur teks, } \\
\text { dan unsur kebahasaan beberapa teks }\end{array}$ & $\begin{array}{l}\text { 3.4.1 mengidentifikasi fungsi sosial, struktur teks, } \\
\text { dan unsur kebahasaan beberapa teks deskriptif } \\
\text { deskriptif lisan dan tulis dengan memberi } \\
\text { lisan dan tulis untuk mendeskripsikan tempat } \\
\text { wisata }\end{array}$ \\
$\begin{array}{l}\text { sederhana terkait orang, benda dan tempat } \\
\text { sesuai dengan konteks penggunaannya. }\end{array}$ & $\begin{array}{l}\text { 3.3.2 menggunakan ungkapan yang berkaitan } \\
\text { dengan tugas sebagai tour guide }\end{array}$ \\
\hline $\begin{array}{l}\text { 4.4 Menyusun teks deskriptif lisan dan tulis, }, \\
\text { pendek dan sederhana, terkait orang, benda }\end{array}$ & $\begin{array}{l}\text { 4.4.3 membuat teks deskriptif lisan dan tulis } \\
\text { tan tempat, dengan memperhatikan fungsi }\end{array}$ \\
$\begin{array}{l}\text { Barat, dengan memperhatikan fungsi sosial, } \\
\text { sosial, struktur teks, dan unsur kebahasaan, }, \\
\text { secara benar dan sesuai konteks }\end{array}$ & $\begin{array}{l}\text { struktur teks, dan unsur kebahasaan, secara benar } \\
\text { dan sesuai konteks. }\end{array}$ \\
\hline
\end{tabular}

Tujuan pembelajaran dari tulisan ini adalah siswa dapat mengidentifikasi fungsi sosial, struktur teks, dan unsur kebahasaan beberapa teks deskriptif lisan dan tulis untuk mendeskripsikan tempat wisata, siswa dapat membuat media Cue Card sebagai media untuk mendeskripsikan tempat wisata di Kalimantan Barat, dan siswa dapat mempresentasikan teks deskriptif untuk mendeskripsikan tempat wisata di Kalimantan Barat.

Oleh karena itu proses belajar mengajar dilaksanakan sesuai dengan tujuan pembelajaran di atas. Siswa pada pertemuan sebelumnya telah dijelaskan tentang apa itu teks deskripsi, sehingga materi yang digunakan dalam penelitian ini terkait dengan materi sebelumnya.
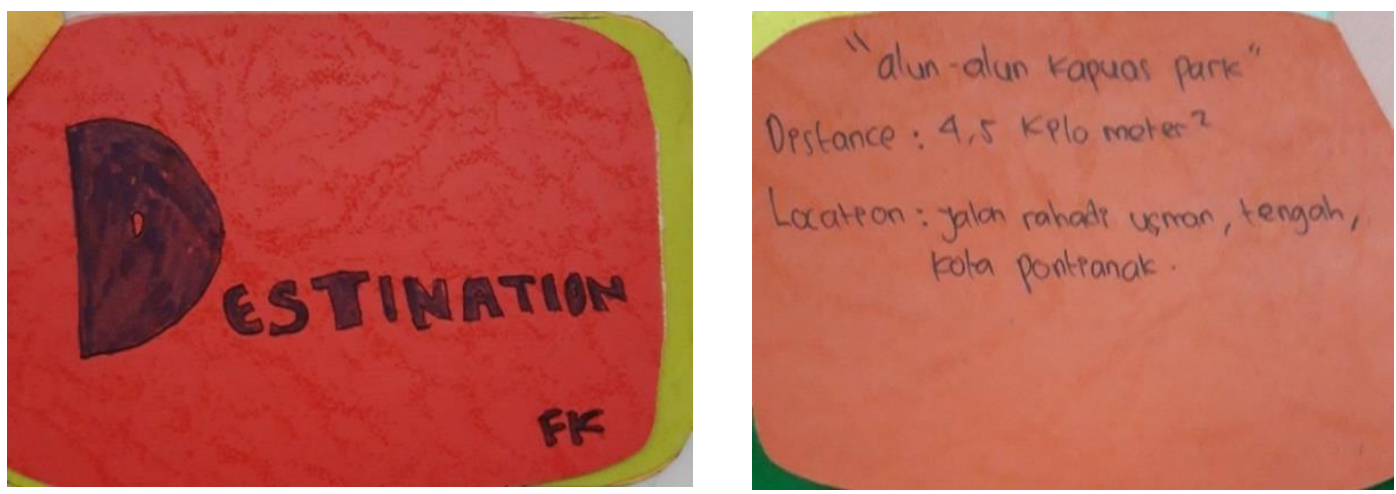

Gambar 2.1. Contoh Cue Card

Ini adalah contoh Cue Card berkaitan dengan deskripsi tempat wisata di Kalimantan Barat. 


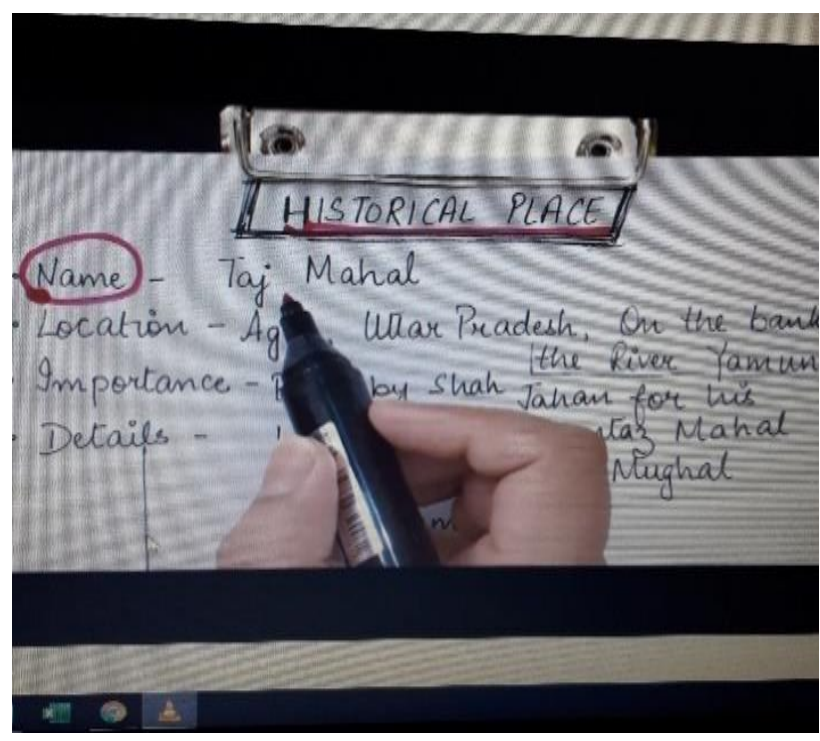

Gambar 2.2. Proses Penayangan Video Tentang Cue Card

Dalam kegiatan awal siswa akan menonton video tentang apa itu Cue Card dan manfaatnya dalam proses pemanduan wisata deskripsi tempat wisata. Secara berkelompok siswa menonton video tentang apa Cue Card dan manfaatnya bagi seorang pramuwisata.

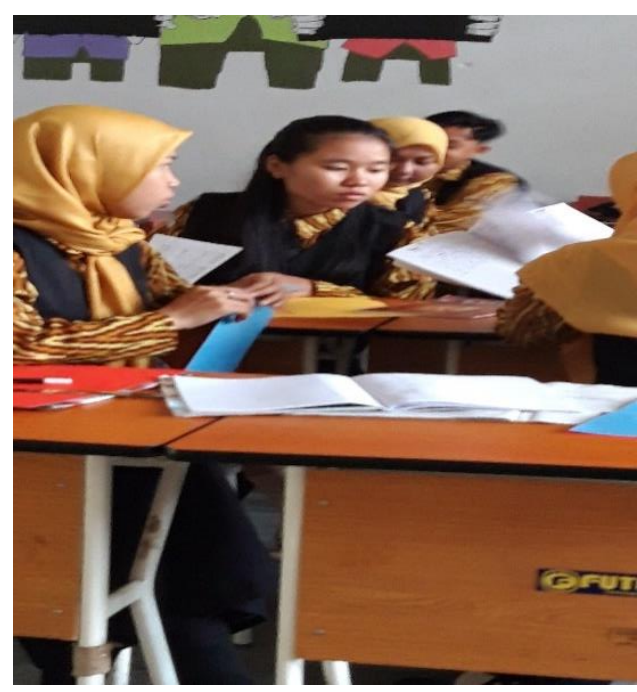

Gambar 2.3. Siswa Berkelompok Mendiskusikan tentang Video Cue Card

Kemudian secara berkelompok siswa menuliskan apa saja topik yang dapat mereka tulis dalam Cue Card untuk mendeskripsikan sebuah tempat wisata. 


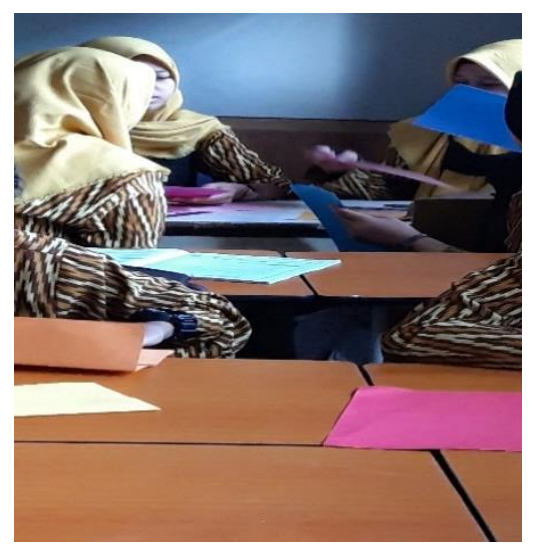

Gambar 2.4. Siswa Mempresentasikan Hasil Diskusi Kelompok

Selanjutnya secara berkelompok siswa mempresentasikan hasil diskusi mereka. Pada kegiatan ini siswa secara berkelompok akan menjelaskan hasil identifikasi mereka tentang apa saja yang mereka dapat tuliskan dalam Cue Card yang akan mereka gunakan dalam praktik pemanduan wisata tentang deskripsi tempat wisata di Kalimantan Barat.



Gambar 2.5 Proses Pembuatan Cue Card

Dalam kegiatan ini secara berkelompok siswa membuat Cue Card yang digunakan untuk praktik pemanduan dalam mendeskripsikan sebuah tempat wisata di Kalimantan Barat. Siswa memulai proses dengan mendesain Cue Card dengan menggunakan kertas buffalo dan kemudian menulis Cue Card tersebut dengan topik-topik yang akan mereka sampaikan pada saat praktik pemanduan tempat wisata di Kalimantan Barat. Siswa menggunakan telepon genggam mereka untuk mencari informasi tentang tempat wisata yang mereka deskripsikan. 

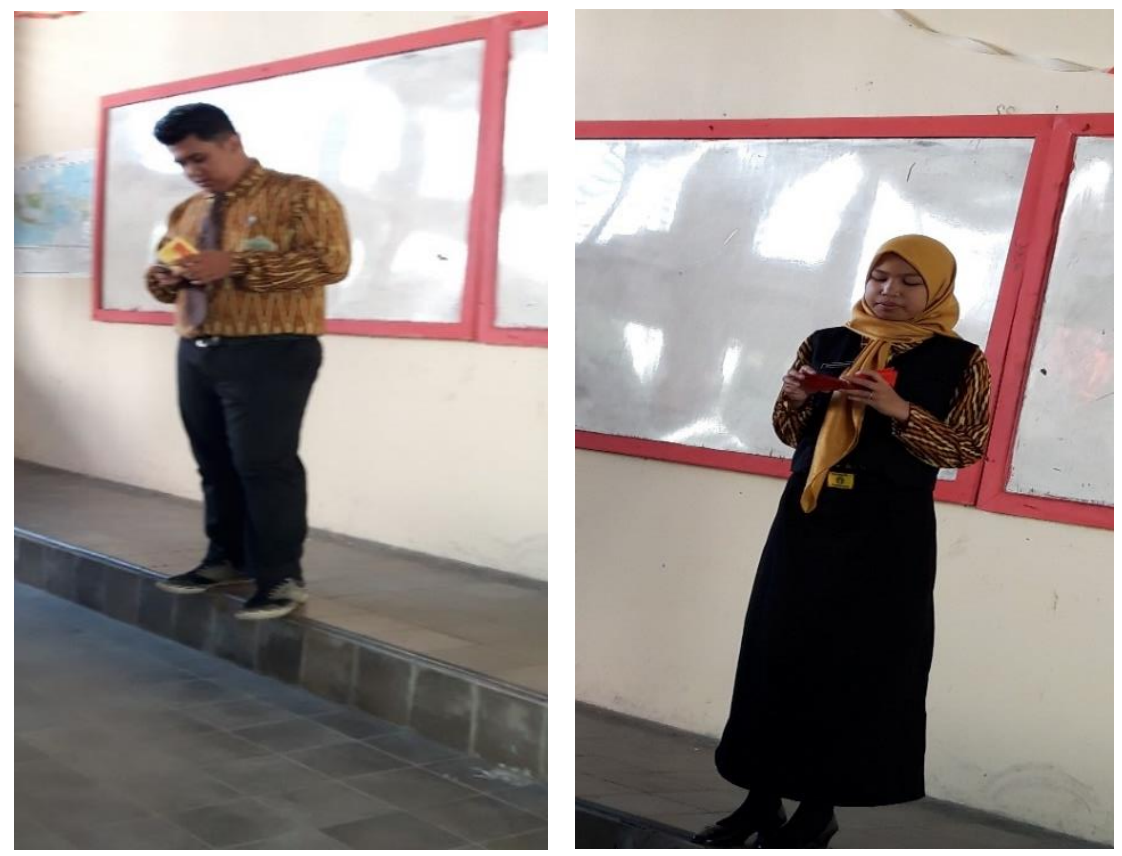

Gambar 2.6 Praktik Pemanduan dengan Menggunakan Cue Card

Siswa melakukan praktik pemanduan wisata dengan cara mendeskripsikan sebuah tempat wisata di Kalimantan Barat berdasarkan Cue Card yang telah mereka buat.

\section{HASIL}

Berdasarkan teori-teori ataupun konsep yang telah diuraikan di depan, kerangka berpikir penelitian ini dapat diterangkan kondisi awal sebelum tindakan dilaksanakan kemampuan berbicara dalam melakukan pemanduan wisata dengan menggunakan Bahasa Inggris siswa kelas X UPW di SMK Negeri 1 Pontianak tahun pembelajaran 2017/2018 rendah. Hal ini dapat kita lihat pada tabel penilaian siswa yang tidak mencapai KKM 75. Media yang digunakan guru terbatas, serta metode mengajar guru dengan menjelaskan, memberikan contoh teks, kemudian siswa menentukan lokasi wisata yang ingin dideskripsikan, mengembangkannya menjadi sebuah teks dan akhirnya siswa diminta untuk menghafal teks tersebut untuk disajikan di depan kelas. Dalam hal ini guru hanya menekankan siswa untuk mengarang dan menghafalkan teks, tanpa membantu bagaimana mereka bisa menguasai materi yang akan mereka sajikan secara lisan. Oleh karena itu, agar kemampuan berbicara siswa meningkat, peneliti melakukan inovasi berupa penggunaan media Cue Card sebagai media siswa dalam melakukan praktik pemanduan wisata dengan menggunakan Bahasa Inggris.

Berdasarkan proses belajar-mengajar dengan menggunakan media Cue Card untuk siswa melakukan praktik pemanduan wisata deskripsi tempat wisata di Kalimantan Barat maka didapatkan hasil yang cukup signifikan dalam peningkatan kemampuan siswa melakukan pemanduan. Sebelumnya sebagian besar siswa menghadapi masalah penguasaan materi tentang deskripsi tempat wisata yang harus mereka lakukan pada saat melakukan praktik pemanduan wisata. Hal ini disebabkan pada saat 
melakukan praktik siswa hanya menghafal dari teks yang mereka telah buat sebelumnya. Padahal proses menghafal adalah proses yang sulit dilakukan oleh sebagian besar siswa ditambah lagi tekanan untuk berbicara di depan umum yang membuat mereka gugup, sehingga semua itu menambah kesulitan mereka dalam melakukan praktik berbicara di depan kelas. Siswa tiba-tiba dapat berhenti untuk memberikan presentasi karena lupa dengan kata-kata yang mereka hafalkan. Hal ini terjadi karena siswa menghafal teks bukan memahami isi teks. Menjadi pengetahuan bersama bahwa menghafal teks apalagi bahasa yang digunakan adalah Bahasa Inggris bukanlah hal yang mudah. Siswa memerlukan cara yang dapat membantu mereka dalam melalukan pemanduan tanpa perlu menghafal teks secara keseluruhan. Oleh karena itu penulis menerapkan media Cue Card dalam membantu siswa melakukan praktik pemanduan dengan menggunakan Bahasa Inggris. Berikut ini adalah Scoring Rubric yang digunakan untuk penilaian presentasi siswa dalam melakukan praktik pemanduan.

Tabel 2.1 Scoring Rubric

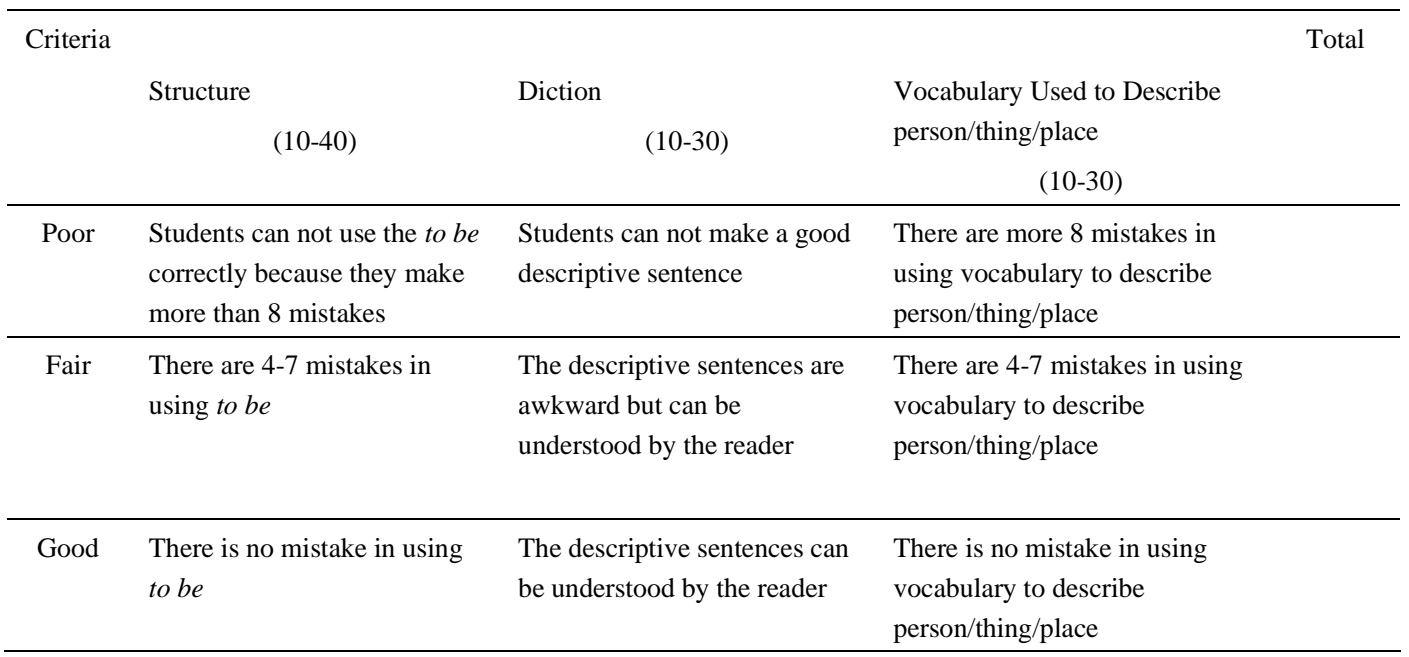

Dengan menggunakan Cue Card siswa sangat terbantu dalam proses melakukan praktik keterampilan berbicara di depan kelas. Hal ini terlihat dari sebagian besar siswa yang lancar dalam melakukan praktik pemanduan tersebut. Jika sebelumnya merasa mendapatkan masalah dengan hafalan, dengan menggunakan Cue Card siswa tidak perlu menghafal teks secara keseluruhan. Hal ini karena topiktopik utama yang harus mereka sampaikan telah terangkum dalam Cue Card tersebut sehingga satu masalah mereka teratasi. Pada saat siswa melakukan praktik berbicara dalam bentuk pemanduan wisata dengan menggunakan Cue Card siswa terlatih untuk menjelaskan sesuatu berdasarkan topik utama, sehingga mereka sedikit demi sedikit belajar bahwa untuk melakukan praktik berbicara dalam Bahasa Inggris mereka tidak harus menghafal kata per kata sehingga jika ada kata atau kalimat yang mereka lupa, maka mereka akan berhenti dan akhirnya mengganggu kelancaran praktik berbicara mereka. Siswa akan terlatih untuk melakukan praktik berbicara monolog berdasarkan konsep yang berisi topik-topik yang penting untuk diingat dan kemudian secara spontan dieksplorasi dan dielaborasi pada saat mereka tampil di depan kelas. Siswa perlu terus berlatih karena pada UKK kelas XII juga mereka harus melakukan pemanduan dalam Bahasa Inggris. 
Poin kedua adalah motivasi siswa untuk melakukan praktik pemanduan meningkat. Jika sebelumnya siswa takut untuk maju ke depan kelas melakukan praktik karena tuntutan menghafal, maka pada saat mereka menggunakan media Cue Card siswa tidak takut lagi untuk maju melakukan praktik. Ketakutan siswa dengan hafalan dapat diatasi dengan Cue Card yang membantu mereka untuk mengingat topik apa yang mereka harus sampaikan pada saat praktik berbicara pemanduan wisata deskripsi tempat wisata di Kalimantan Barat. Dengan meningkatnya motivasi siswa maka proses pembelajaran dapat berjalan dengan aktif. Berdasarkan hasil tersebut dapat dikatakan bahwa Cue Card dapat meningkatkan ketrampilan berbicara siswa sebagai pramuwisata dalam mendeskripsikan tempat wisata di Kalimantan Barat.

Tabel 2.2 Perbandingan Nilai 1 dan Nilai 2

\begin{tabular}{|c|c|c|c|}
\hline NO & NAMA & N1 & N2 \\
\hline 1 & $\mathrm{~A}$ & 70 & 85 \\
\hline 2 & $\mathrm{AXN}$ & 60 & 85 \\
\hline 3 & $\mathrm{CA}$ & 72 & 85 \\
\hline 4 & $\mathrm{DC}$ & 85 & 80 \\
\hline 5 & DO & 72 & 85 \\
\hline 6 & ESP & 70 & 75 \\
\hline 7 & Fan & 65 & 85 \\
\hline 8 & Fap & 75 & 85 \\
\hline 9 & $\mathrm{FN}$ & 58 & 78 \\
\hline 10 & $\mathrm{HH}$ & 76 & 85 \\
\hline 11 & $\mathrm{~J}$ & 73 & 78 \\
\hline 12 & $\mathrm{JC}$ & 67 & 85 \\
\hline 13 & MFF & 73 & 88 \\
\hline 14 & MT & 61 & 85 \\
\hline 15 & $\mathrm{MH}$ & 74 & 85 \\
\hline 16 & $\mathrm{~N}$ & 73 & 85 \\
\hline 17 & NA & 76 & 85 \\
\hline 18 & Ini & 74 & 85 \\
\hline 19 & RRR & 66 & 85 \\
\hline 20 & RMA & 73 & 88 \\
\hline 21 & $\mathrm{RP}$ & 71 & 85 \\
\hline 22 & RAP & 75 & 85 \\
\hline 23 & RA & 60 & 80 \\
\hline 24 & ST & 72 & 80 \\
\hline 25 & SCJ & 58 & 85 \\
\hline 26 & SR & 65 & 85 \\
\hline 27 & SA & 72 & 85 \\
\hline
\end{tabular}

Tabel di atas menampilkan nilai 1 praktik pemanduan tanpa Cue Card dan nilai 2 praktik pemanduan dengan menggunakan Cue Card. 
Penelitian ini dapat terlaksana dengan lancar dengan dukungan situasi kelas yang kondusif dan siswa yang aktif dalam melakukan proses pembelajaran di kelas. Kelas yang kondusif memungkinkan siswa untuk bekerja membuat Cue Card dengan aktif, lancar dan nyaman. Sedangkan siswa yang aktif membuat proses pembelajaran dari pembuatan Cue Card sampai praktik pemanduan dapat berjalan dengan lancar. Sedangkan hambatan yang muncul terutama pada saat presentasi. Ada beberapa siswa yang tetap kesulitan dalam melakukan praktik pemanduan di depan kelas karena gugup. Oleh karena itu beberapa siswa tersebut perlu mendapatkan perhatian dan bimbingan yang lebih banyak.

Sebagai tindak lanjut, penulis berharap bahwa keterampilan berbicara dalam Bahasa Inggris siswa UPW semakin meningkat. Sehingga mereka dapat melakukan praktik pemanduan tanpa harus ada media alat bantu, karena dengan seringnya mereka melakukan praktik berbicara tanpa harus menghafal teks tapi dengan mengingat konsep topik yang harus disajikan maka siswa dapat mengatasi masalah mereka dalam melakukan praktik pemanduan dengan menggunakan Bahasa Inggris. Kemudian berkaitan dengan era industri 4.0 yang banyak menggunakan sistem digital, maka digitalisasi pendidikan sangat diperlukan baik dalam bentuk media pembelajaran maupun bahan pembelajaran itu sendiri.

\section{SIMPULAN DAN SARAN}

Berdasarkan pembahasan di atas, Media Cue Card dapat digunakan untuk meningkatkan keterampilan berbicara siswa sebagai pramuwisata dalam mendeskripsikan tempat wisata di kelas X UPW SMK Negeri 1 Pontianak.

1. Proses pembelajaran dengan menggunakan media Cue Card untuk meningkatkan keterampilan berbicara siswa sebagai pramuwisata dalam mendeskripsikan tempat wisata di Kelas X UPW SMK Negeri 1 Pontianak dimulai dari kegiatan siswa menonton tentang apa itu Cue Card, proses pembuatan $C$ ue Card dan proses praktik pemanduan wisata tentang deskripsi tempat wisata di Kalimantan Barat dengan menggunakan Cue Card.

2. Inovasi pembelajaran dengan menggunakan media Cue Card untuk meningkatkan keterampilan berbicara siswa sebagai pramuwisata dalam mendeskripsikan tempat wisata di Kelas X UPW SMK Negeri 1 Pontianak efektif meningkatkan keterampilan siswa dalam melakukan pemanduan wisata. Hal ini dibuktikan dari lancarnya siswa dalam melakukan praktik pemanduan dalam Bahasa Inggris dan meningkatnya motivasi siswa dalam melakukan praktik tersebut.

3. Peningkatan keterampilan siswa tersebut menunjukkan bahwa Cue Card efektif digunakan sebagai media dalam proses pembelajaran.

Saran yang dapat diberikan adalah sebagai berikut:

1. Guru perlu lebih kreatif dalam melakukan inovasi pembelajaran sehingga siswa dapat meningkatkan kemampuan mereka dengan baik.

2. Pihak sekolah perlu memberikan fasilitas dan pelatihan kepada guru sehingga guru dapat meningkatkan wawasan dan kemampuannya dalam mengembangkan inovasi pembelajaran.

3. Pemerintah perlu meningkatkan kesempatan pada guru untuk mengembangkan diri mereka. 


\section{DAFTAR RUJUKAN}

Arikunto, S. (2000). Prosedur Penelitian. Suatu Pendekatan Praktik, Jakarta: Rineka Cipta.

Brown, H. D. (2001). Teaching by Principles. New York: Wendy Wolf.

Brown, H. D. (2003). Language Assessment Principle Classroom Practice. New York: Longman.

Harmer, J. (2007). The Practice of English Language Teaching. Longman Handbooks for Language Teachers.

Kane, S. T. (1988). Essential Guide to Writing. Oxford University Press.Inc

Nunan, D. (2003). Practical English language teaching. New York, NY: McGraw-Hill.

Provost, T. (2014). "How to Write a Descriptive Paragraph", (2009). http://www.howtodothing.com/education/how-to-write-a-descriptive-pragraph.

Reiser, R. A \& Dick, W. (1996). Instructional Planning: A Guide for Teachers. United States of America: a Simon \& Schuster Company.

Zemach, D.E. \& Islam, C. (2005). Paragraph Writing: From Sentence to Paragraph. Oxford: Macmillan Publisher, 2005. 